\title{
The Impact of Market Knowledge Acquisition on Product Innovation Performance in Small and Medium Scale Enterprises
}

Bernice Korkor Gligah, Norzaidahwati Zaidin, Eugene Okyere-Kwakye

To Link this Article: http://dx.doi.org/10.6007/IJARBSS/v11-i10/10916 DOI:10.6007/IJARBSS/v11-i10/10916

Received: 07 August 2021, Revised: 28 August 2021, Accepted: 20 September 2021

Published Online: 02 October 2021

In-Text Citation: (Gligah et al., 2021)

To Cite this Article: Gligah, B. K., Zaidin, N., \& Okyere-Kwakye, E. (2021). The Impact of Market Knowledge Acquisition on Product Innovation Performance in Small and Medium Scale Enterprises. International Journal of Academic Research in Business and Social Sciences, 11(10), 80-92.

Copyright: (c) 2021 The Author(s)

Published by Human Resource Management Academic Research Society (www.hrmars.com)

This article is published under the Creative Commons Attribution (CC BY 4.0) license. Anyone may reproduce, distribute, translate and create derivative works of this article (for both commercial and non-commercial purposes), subject to full attribution to the original publication and authors. The full terms of this license may be seen at: http://creativecommons.org/licences/by/4.0/legalcode

Vol. 11, No. 10, 2021, Pg. 80 - 92

Full Terms \& Conditions of access and use can be found at http://hrmars.com/index.php/pages/detail/publication-ethics 


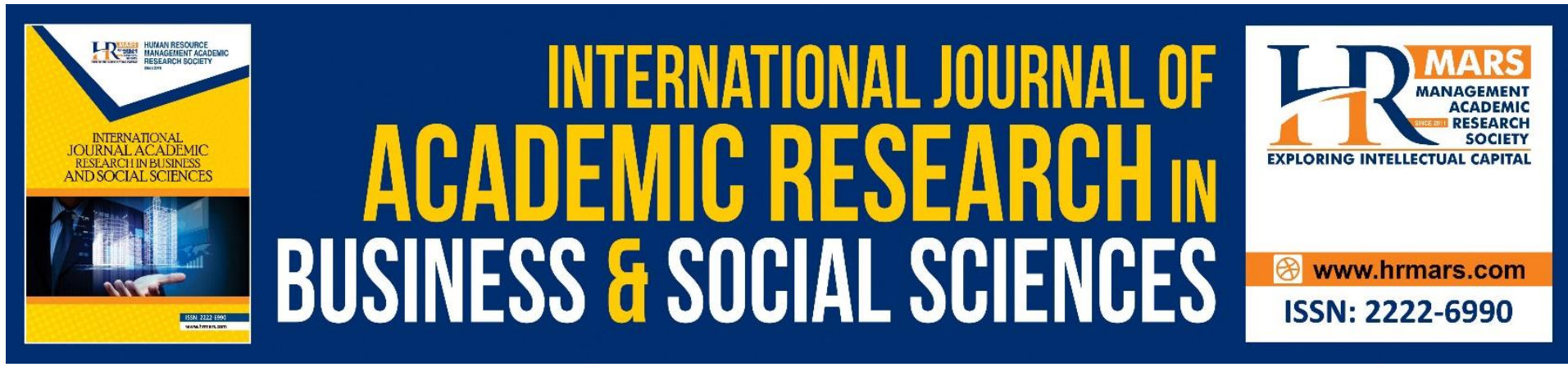

\title{
The Impact of Market Knowledge Acquisition on Product Innovation Performance in Small and Medium Scale Enterprises
}

\author{
Bernice Korkor Gligah \\ Azman Hashim International Business School, Universiti Teknologi Malaysia, 81310 UTM, \\ Skudai, Malaysia, Faculty of Business and Management Studies, Koforidua Technical \\ University, Ghana \\ Email: bernicekorkor@graduate.utm.my,gkbernice@ktu.edu.gh
}

Norzaidahwati Zaidin

Senior Lecturer and Marketing Research Group Leader, Azman Hashim International Business School, Universiti Teknologi Malaysia, 81310 UTM, Skudai, Malaysia.

\section{Eugene Okyere-Kwakye}

Senior Lecturer and the Head of Department (General Studies), Faculty of Business and Management Studies, Koforidua Technical University, Ghana.

\begin{abstract}
This paper aimed to determine the relative impact of market knowledge acquisition (knowledge gained from customers, and competitors') acts on product innovation performance in smaller firms. Based on data collected through a convenience sampling technique, survey questions of 462 SME operators, and a review of user-generated content, this study provides a look into the market knowledge of Ghanaian manufacturing micro, small, and medium scale enterprises in the eastern sector. The traditional double-step model was used to evaluate the measurement model and then estimate the structural model using SPSS and Smart PLS (Partial Least Square). The outcome of the study revealed two [2] out of the four [4] hypotheses supported; the findings showed that market knowledge acquisition which comprised customers' and competitors' knowledge remains critical drivers of product innovation performance. Meanwhile, the study revealed firm absorptive capacity does not moderate market knowledge acquisition and product innovation performance.
\end{abstract}

Keywords: Market Knowledge Acquisition, Small Medium Scale Enterprises, Firm Absorptive Capacity, Product Innovation Performance, Ghana.

\section{Introduction}

Studies have discussed the importance of market knowledge, marketing capabilities, and the ability of firms to leverage it to enhance performance, meanwhile this issue which has earned limited research attention (Falasca et al., 2017; Hoe, 2008; Thongsri \& Chang, 
2019). Meanwhile, more research has concentrated on customer knowledge to the detriment of competitor knowledge (Dwyer \& Gilmore, 2019), the inclusion of competitor knowledge in the SME context presents a unique area to explore. The main objective of this paper is to investigate the firm's market knowledge acquisition (MKA) comprising customer and competitor knowledge, the moderating effect of firm absorptive capacity (FAC), and product innovation performance (PIP). Such a research study will extend literature since no prior studies looked for each of these interactions at the same time Ghanaian manufacturing SME context.

A conceptual framework is presented to achieve the given research goal. Using survey instruments, the proposed interaction is examined and findings discussed. Review of literature, theoretical guidance, research hypotheses, methodology, results and findings are discussed accordingly. Conclusion, implications, and limitation paths are also addressed for future research.

\section{Literature Review \\ Market Knowledge}

Market-based knowledge acquisition refers to how the market behaves by understanding customers and competitors well to enhance firm capability in innovation (Evangelista \& Mac, 2016). It thus concerns issues about the tastes, backgrounds, experiences of both customers and competitors in the market space and its effect has been explored by marketing researchers (Aminu, 2018; Leng, Liu, Tan, \& Pang, 2015; Li, Xie, \& Cheng, 2017; Taghizadeh et al., 2018; Verhees \& Meulenberg, 2004). Researchers' indicate that customer consumption patterns, and preferences are all linked to customer knowledge (Taghizadeh, et al., 2018). In the conceptualization of customer knowledge by Taghizadeh, Rahman, \& Hossain (2018), they categorized customer knowledge into knowledge from the customer, for the customer, and about the customer. Knowledge from customer refers to knowledge which is sourced from the customers which could take the form of face to face means, knowledge for customer relates to the information and dataset that the firm offers in satisfaction of the customers' requirements and finally, knowledge about the customer explains customer desires, taste, needs and tastes to envisage their future needs and wants to inform themselves which will transcend into innovative steps being taken by the firm. Close interactions with customers and market activities are therefore an anchor in obtaining and utilizing knowledge in their everyday activities to enhance innovation (Dabrowski, 2019; Falasca et al., 2017; Herman, Hady, \& Arafah, 2018; Uğurlu, Kurt, \& Kurt, 2016).

Competitor knowledge acquisition, on the other hand, relates to a firm's capacity and desire to detect, evaluate, and predict competitors' acts (Dwyer \& Gilmore, 2019). Competitors' initiatives, plans, and possible reactions may necessitate new product development particularly for companies competing in sectors with intensive and competitive markets (Wang \& Wang, 2016). Changes in the market may lead firms to acquire competitor knowledge to respond accordingly (Liu \& Atuahene-Gima, 2018). Subsequently, this research aims to study firm product innovation performance through market knowledge acquisition.

\section{Product Innovation Performance (PIP)}

The definition of firm performance remains unclear in the literature; it is a multidimensional construct (Tuan et.al. 2016). It is a multifaceted and complex construct (Expósito $\&$ Sanchis, 2019). That is, it tackles a range of interrelated metrics, such as growth results (Nastasiea \& Mironeasa, 2015), quality, innovation and creativity(Wadho \& Chaudhry, 2018), 
personnel participation (Sinisammal et al., 2012; Sousa et al., 2018), customer satisfaction (Fong, Lo, \& Ramayah, 2014) and even productivity (Kumar \& Rahman, 2015; Fu et al., 2018). Also measures such as customers, efficiency, employees, systems, and procedures have been studied (Fong et al., 2014; ;Tuan et al., 2016). Writers have also suggested others such as underutilization of higher capacity is a crucial factor that hinders the growth of several SMEs in Africa (Ahiakpor, Asmah \& Andoh, 2014). Consequently, organizational performance research is very wide and diverse and keeps expanding as multiple aspects of management practices are becoming more and more important to researchers (Kalay \& Lynn, 2015).

Each enterprise has its own definition of business performance which depends on its context meanwhile, researchers have argue for a combination of performance measures (KSHATRIYA, et al., 2017; Maduekwe, et al., 2016). Estimating performance thus serves the purpose of ensuring that a firm pursues measures that will lead to the achievement of the overall goals and objectives (Fong et al., 2014). Measuring performance is thus varied, which could be based on a variety of factors.

It is however evident that the notion of performance has many interpretations for various researchers (Njoroge, 2016; Olaru, Pirnea, et al., 2014; Tuan et al., 2016). In light of this, the study therefore examines firms' PIP through new product lines, sales volume growth, production volume growth, and capacity utilization to assess PIP.

\section{The Relation between Market Knowledge and Product Innovation Performance}

In transforming new product designs/processes, customers are regarded as a wealth of knowledge resources available on the market (Storey \& Larbig,2018), innovation initiation process of firms by increasingly making inputs in the operations and innovation activities of firms for firms to meet the requirements and taste of the market (Dabrowski, 2019). The use of customer knowledge has evolved in the advancement of business activities, it has increasingly become a vital issue in today's dynamic environment (Schaarschmidt \& Walsh, 2018; Yachin, 2018).

According to Evangelista \& Mac, 2016, when firms interact with customers through customer inquiries, customer requests, customer preferences, complaints, or series of actions leading to responses; these presents opportunity for firms to acquire/ gain knowledge likewise when firms engage with competitors over time, it accumulates both explicit and tacit knowledge. In effect, customers are engaged in sharing their experience and knowledge between themselves and the firms. In the view of Zhang \& Conchar, (2017), they indicate that firms' customer knowledge has a positive effects on product innovation. Likewise, Schaarschmidt \& Walsh (2018) focusing on customer interaction in the B2B business, asserts beneficial customer interaction.

Firms can therefore take advantage of these exchange processes in employing innovative measures to ensure firm sustainability.

Storey \& Larbig, (2018) have however argued that customer involvement on its own cannot guarantee success. Refusal to understand competitors, on either side will render SMEs oblivious of the extent and effect of competitor activities, and how knowledge of competing companies can be an enabler of competitiveness (Dwyer \& Gilmore, 2019). Given that SMEs are generally creative in their use of creative methods to solve the limitations imposed by their size, paying significant attention to market knowledge to gaining innovativeness is a sure way (Dabrowski, 2019; Mostafiz, Mdlmtiaz, et al., 2019). The ongoing discussions lead the study to hypothesize that: 
$H_{0}$ 1: Customer knowledge acquisition is positively related to SME product innovation performance.

Ho2: Competitor knowledge acquisition is positively related to SME product innovation performance.

\section{Moderating Role of Firm Absorptive Capacity}

Given that organizations need to be as efficacious and innovative as possible, they need to fully integrate new knowledge from both outlets (Lewandowska, 2015). The firm becomes more knowledgeable in seeking, gaining, and incorporating information through direct exposure and interaction in market activities (Cohen \& Levinthal, 1990; Liao \& Barnes, 2015; Mensah, 2019; Salehi, 2017; Shane, 2000) especially among smaller enterprises (Hilmersson \& Johanson, 2020; Liao \& Barnes, 2015). The theory of absorptive capacity has been used in some research to evaluate the technological as well as innovation capabilities of firms (Aljanabi, 2018; Flor, Cooper, \& Oltra, 2018; Najafi-Tavani et al., 2018; Vlačić, Dabić, Daim, \& Vlajčić, 2019).

There is a strong indication of R\&D investments boosting a firm's knowledge and innovative abilities (Ferraris et al., 2019; Flor et al., 2018; Hameed et al., 2018). That notwithstanding, SMEs minimal R\&D activities (Davcik et al., 2020; Santoro, Ferraris et al., 2019; Thomä \& Zimmermann, 2020), leads the study to adapt human capital dimension which is thought to be more appropriate (AlQershi, et al., 2020; Ferreira \& Franco, 2019; He, et al., 2020; Flatten et al., 2011).

Drawing on the tenets of SME human capital, this study drew on the customer and competitor knowledge experience of the management team as well as the firm's relevant formal training or university degree. Given that, firm absorptive capacity enables the adaptation of knowledge in value creation (Carson, et al., 2020; Varadarajan, 2020). The expected moderating effect of FAC in the interaction between MKA (CUK and COK) and firm PIP is captured in the hypotheses below:

$H_{0} 3 a:$ FAC moderates the relationship between Customer knowledge acquisition and SME Product Innovation Performance.

$\boldsymbol{H}_{0} 3 \mathrm{~b}$ : $F A C$ moderates the relationship between Competitor knowledge acquisition and SME Product Innovation Performance. 
The hypotheses is shown in Figure 1 below:

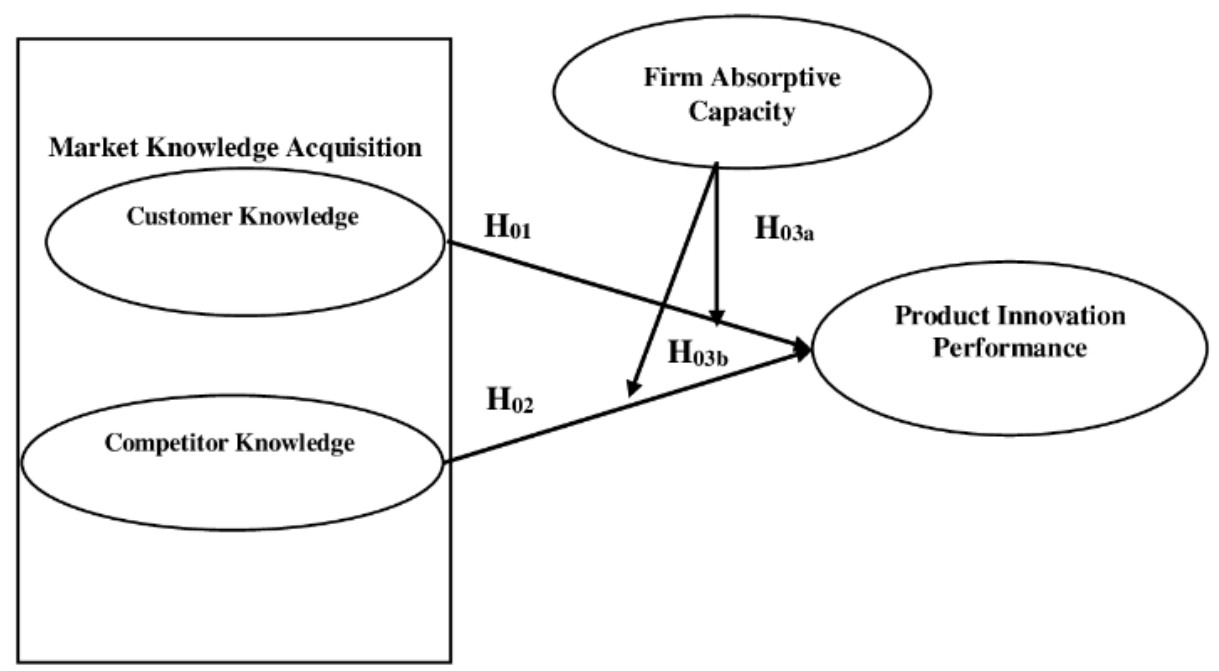

Figure 1: Research Model

Research Instrument: The study employed a survey method of data collection. The conceptual model was tested empirically in the SME manufacturing setting via a survey questionnaire. The questionnaire was sent directly to the owners, owner-managers, managers, and/or proxies of 500 manufacturing firms in the eastern region of Ghana to SME manufacturing operators. It included 14 items comprising to the three main variables used, in addition nine items were used to assess the demographic characteristics. Using a five-point Likert scale, each item was measured. Seven items adapted from Bojica \& Fuentes-fuentes, (2019); Wang \& Wang (2016), MKA was utilized. Questions on customer knowledge acquisition are shown in the initial three items, followed by competitor knowledge acquisition. The MKA scale score was determined by adding the responses for each of the seven items. FAC was determined by three items modified from the works of Evangelista \& Mac, (2016); Muscio, (2007). Four items from Lin, \& Chen, (2007) were used to operationalize the last scale, PIP questions on the introduction of new product lines, sales volume growth, production volume growth, and capacity utilization.

Sample and Data Collection: With a study sample of 500 manufacturing SMEs in the eastern region of Ghana, a total of 320 were distributed to respondents at their workplaces while the remaining were administered via online-based questionnaires. Some 7.5 percent of the 500 questionnaires were excluded because of incomplete answers. The study received 462 valid responses, yielding a response rate of 92 percent. Using the time trend method, non-response bias was evaluated (Armstrong and Overton, 1977). A comparison-of-means analysis was performed on the data collected from the early, mid, and late respondents (roughly two weeks apart). The research instrument underwent additional pre-testing using 25 respondents to ensure content validity as well as enhancing the practical relevance and applicability.

Data Analysis: Smart PLS 3 software and the Statistical Package for Social Sciences (SPSS) version 23 were utilized to conduct inferential statistics and descriptive statistics respectively. The data collected was coded, cleaned, and prepared for analysis. SEM's stoutness makes it an appropriate tool capable of testing the entire model simultaneously and assessing measurement errors (Awang, 2012). PLS-SEM algorithm's iterative procedure was utilized using-500 selected value based on the maximum number of iterations to obtain 
final results. The study's hypotheses were examined based on the measurement model's confidence level.

Cross loading and Fornell and Larcker criterion were used to determine discriminant validity (Hair et al., 2014). Hetero trait-Mono trait (HTMT), was also developed to arrest the insensitivity of the Fornell and Larcker and cross-loading criterion of ratio (Henseler, Ringer \& Sarstedt, 2015). The variance-inflated factor was used to determine collinearity among latent variance. The threshold value included VIF $\geq 5$ to depict potential collinearity problems (Hair et al., 2011).

\section{Results}

\section{Demographic Characteristics of Respondents}

The responses indicates majority are male (278) representing 60.2\% and 184 representing $39.8 \%$ are females. This implies that more males are in the SME manufacturing sector than their female counterparts. 206 respondents (44.6\%) fall within the 31-40 years followed by 164 (35.5\%) fell between 18 - 30 years. Ninety (90) respondents representing $19.5 \%$ were between $41-50$ years. Only 2 out of 462 respondents were above 50 years; representing $4 \%$. This implies majority of the Ghanaian SMEs are in their youth. A number of SME operators' educational backgrounds fell within Diploma and Bachelor Degree holders with a few having BECE and below. In other words, while 282 people made up $61 \%$ of the survey, have above Bachelor Degree, only 48 representing 10.3 percent having BECE and below in the manufacturing sector. This indicates that more educated people in Ghana are venturing into the SME manufacturing sector. And with the majority of the manufacturing SMEs having between 6-10 years of manufacturing experience, it affirms more manufacturing SMEs in Ghana operating over the years; while 154 depicting 33.3\% has operated between 610 years, 80 representing 17.3 percent have operated between $11-15$ years, 30 respondents which represent 6.5 percent of the respondents have accumulated experience of 16 years and above, and finally, 198 representing 42.9 percent have 5 years and below work experience. This confirms the dominance of businesses in Ghana with less than 5 years of existence and experience. Further demographic information is presented in table 1 below. 
INTERNATIONAL JOURNAL OF ACADEMIC RESEARCH IN BUSINESS AND SOCIAL SCIENCES Vol. 11, No. 10, 2021, E-ISSN: 2222-6990 @ 2021 HRMARS

Table 1: Demographic Characteristics of Respondents

\begin{tabular}{|c|c|c|c|}
\hline Variables & Category & Frequency & Percent \\
\hline \multirow[t]{2}{*}{ Gender } & Female & 184 & 39.8 \\
\hline & Male & 278 & 60.2 \\
\hline \multirow[t]{4}{*}{ Age } & $18-30$ years & 164 & 35.5 \\
\hline & $31-40$ years & 206 & 44.6 \\
\hline & $41-50$ years & 90 & 19.5 \\
\hline & Above 50 years & 2 & .4 \\
\hline \multirow[t]{6}{*}{ Education } & Bachelor Degree & 136 & 29.4 \\
\hline & Diploma & 146 & 31.6 \\
\hline & $\begin{array}{l}\text { Graduate Studies (Master } \\
\text { and Ph.D.) }\end{array}$ & 32 & 6.9 \\
\hline & Junior High School (BECE) & 46 & 9.9 \\
\hline & Primary education & 2 & .4 \\
\hline & Senior High School & 100 & 21.6 \\
\hline \multirow[t]{5}{*}{ Position } & Business Owner & 164 & 35.5 \\
\hline & Business Owner \& Manager & 120 & 26.0 \\
\hline & Employee (proxy) & 40 & 8.6 \\
\hline & Manager & 90 & 19.5 \\
\hline & Production Manager & 48 & 10.4 \\
\hline \multirow[t]{4}{*}{ Experience } & $1-5$ years & 198 & 42.9 \\
\hline & $11-15$ years & 80 & 17.3 \\
\hline & 16 years and above & 30 & 6.5 \\
\hline & $6-10$ years & 154 & 33.3 \\
\hline \multirow[t]{4}{*}{$\begin{array}{ll}\text { Number } & \text { of } \\
\text { Employees } & \\
\end{array}$} & 1- 5 employees & 222 & 48.1 \\
\hline & 100 or more employees & 14 & 3.0 \\
\hline & $30-99$ employees & 28 & 6.1 \\
\hline & $6-29$ employees & 198 & 42.9 \\
\hline \multirow[t]{3}{*}{ Product } & 1-2 Products & 126 & 27.3 \\
\hline & 3-5 Products & 142 & 30.7 \\
\hline & More than 5 Products & 194 & 42.0 \\
\hline \multirow[t]{3}{*}{ Years of Operation } & 1 to 5 years & 158 & 34.2 \\
\hline & 6 to 10 years & 198 & 42.9 \\
\hline & More than 10 years & 106 & 22.9 \\
\hline \multirow[t]{9}{*}{ Business Type } & Cosmetics & 34 & 7.4 \\
\hline & Fashion & 72 & 15.6 \\
\hline & Food Processing & 100 & 21.6 \\
\hline & Metal Fabrication & 58 & 12.6 \\
\hline & Pharmaceuticals & 42 & 9.1 \\
\hline & Poultry & 68 & 14.7 \\
\hline & Textiles & 48 & 10.4 \\
\hline & Others & 40 & 8.7 \\
\hline & Total & 462 & 100.0 \\
\hline
\end{tabular}




\section{Descriptive and Correlation Analyses}

Table 1 also showed that Customer Knowledge Acquisition scored (Mean $=4.18$; $\mathrm{SD}=0.647$ ). Competitor Knowledge Acquisition scored (Mean $=3.95 ; \mathrm{SD}=0.786$ ). Firm Absorptive Capacity scored (Mean $=3.65 ; \mathrm{SD}=0.808$ ) and Product Innovation Performance scored (Mean $=4.21 ; \mathrm{SD}=0.747$ ). The descriptive analysis shows that Market Knowledge Acquisition (Customer Knowledge and Competitor Knowledge) and Firm Absorptive Capacity scored mean above 3.50 indicating that these factors play important role in enhancing Product Innovation Performance among SMEs in Ghana. Table 2 further shows that the correlation analysis showed a significant positive association between all the constructs (Customer Knowledge, Competitor Knowledge and Absorptive Capacity) and Product Innovation Performance among SMEs in Ghana $(r=.414, P<.01 ; r=.224, P<.01$ and $r=.382$, $\mathrm{P}<.01)$ respectively. Thus, the higher level of Customer Knowledge, Competitor Knowledge, and Absorptive Capacity is associated with higher Product Innovation Performance among SMEs in Ghana. Again, the highest correlation among the independent variables is $r=.538$, hence indicating the absence of multicollinearity.

Table 2 Descriptive Statistics and Correlation Analysis

\begin{tabular}{lllllll}
\hline Constructs & Mean & $\begin{array}{l}\text { Std. } \\
\text { Deviation }\end{array}$ & $\mathbf{1}$ & $\mathbf{2}$ & $\mathbf{3}$ & $\mathbf{4}$ \\
\hline 1. PIP & 4.21 & .747 & 1 & & & \\
2. CUK & 4.18 & .647 & $.414^{* *}$ & 1 & & \\
3. COK & 3.95 & .786 & $.224^{* *}$ & $.538^{* *}$ & 1 & \\
4. ABC & 3.65 & .808 & $.382^{* *}$ & $.388^{* *}$ & $.390^{* *}$ & 1 \\
\hline
\end{tabular}

**. Correlation is significant at the 0.01 level (2-tailed).

CUK=Customer Knowledge: $C O K=$ Competitor Knowledge; FAC=Firm Absorptive Capacity and $P I P=$ Product Innovation Performance

\section{Structural Equation Modelling (SEM)}

The study employed Structural Equation Modelling (SEM) using Smart PLS as a statistical method to examine the behaviour/ nature of relationship that exist among the constructs used in the study (Hair et al.,2017; Wong et al.,2019). The result comprised structural model assessment and the model measurement assessment. While the model measurement explores the relationship among the latent constructs and observed variables and to provide validity and reliability of the variables used in this study, the structural model examines the direction and strength of the path.

\section{Measurement Model Assessment}

In the quest to establish model measurement quality, confirmatory factor analysis was conducted. The CFA was done to ascertain the validity and reliability of the constructs used in the study. As per the recommendations of previous studies (Voorhees, Brady, Calantone \& Ramirez, 2016: Ab Hamid, Sami\& Sidek, 2017), it remain imperative to establish the validity and reliability of the study constructs before proceeding to any hypotheses testing. The authors used reliability, convergent validity and divergent validity to test the measurement model quality and to confirm the stability of the latent constructs. The results of the measurement model assessment are discussed below in Table 4. 
Table 3: Validity and Reliability

\begin{tabular}{|l|l|l|l|l|l|l|l|}
\hline Constructs & Items & Loadings & CA & rho_A & CR & AVE & VIF \\
\hline $\begin{array}{l}\text { Absorptive } \\
\text { Capacity }\end{array}$ & FAC1 & 0.896 & 0.708 & 0.716 & 0.872 & 0.773 & 1.428 \\
\hline & FAC2 & 0.862 & & & & & 1.428 \\
\hline $\begin{array}{l}\text { Customer } \\
\text { Knowledge }\end{array}$ & CUK1 & 0.750 & 0.666 & 0.672 & 0.816 & 0.597 & 1.371 \\
\hline & CUK3 & 0.790 & & & & & 1.332 \\
\hline & CUK4 & 0.777 & & & & & 1.228 \\
\hline $\begin{array}{l}\text { Competitor } \\
\text { Knowledge }\end{array}$ & COM1 & 0.760 & 0.787 & 0.849 & 0.868 & 0.688 & 1.774 \\
\hline & COM2 & 0.857 & & & & & 1.894 \\
\hline & COM3 & 0.867 & & & & & 1.466 \\
\hline $\begin{array}{l}\text { Product } \\
\text { Innovation } \\
\text { Performance }\end{array}$ & PIP1 & 0.741 & 0.790 & 0.801 & 0.865 & 0.616 & 1.511 \\
\hline & PIP2 & 0.862 & & & & & 2.073 \\
\hline & PIP3 & 0.803 & & & & & 1.610 \\
\hline & PIP4 & 0.725 & & & & & 1.567 \\
\hline
\end{tabular}

Table 4: Discriminant Validity

\begin{tabular}{|l|l|l|l|l|}
\hline Constructs & $\mathbf{1}$ & $\mathbf{2}$ & $\mathbf{3}$ & $\mathbf{4}$ \\
\hline 1. Firm Absorptive Capacity & 0.879 & & & \\
\hline 2. Competitor Knowledge & 0.436 & 0.829 & & \\
\hline 3. Customer Knowledge & 0.446 & 0.610 & 0.772 & \\
\hline $\begin{array}{l}\text { 4. Product Innovation } \\
\text { Performance }\end{array}$ & 0.540 & 0.364 & 0.595 & 0.785 \\
\hline
\end{tabular}

Table 5: Heterotrait-Monotrait Ratio (HTMT)

\begin{tabular}{|l|l|l|l|l|}
\hline Constructs & $\mathbf{1}$ & $\mathbf{2}$ & $\mathbf{3}$ & $\mathbf{4}$ \\
\hline 1. Firm Absorptive Capacity & & & & \\
\hline 2. Competitor Knowledge & 0.569 & & & \\
\hline 3. Customer Knowledge & 0.638 & 0.798 & & \\
\hline $\begin{array}{l}\text { 4. Product Innovation } \\
\text { Performance }\end{array}$ & 0.718 & 0.431 & 0.803 & \\
\hline
\end{tabular}

The study employed CFA to assess the validity and reliability of the constructs used in the study. The study used composite reliability. The result showed good construct reliability. All the latent variables showed CR values above 0.7 as recommended by Hair et al. (2010). The study further explored internal consistency of the latent variables using Cronbach Alpha. The result as presented in Table 2 revealed that all the latent variables recorded CA values above 0.6 threshold recommended by (Huang et al., 2017; Nuanally and Berntein, 1994). AVE was further employed to examine convergent validity. The result of the AVE showed that all the constructs scored AVE values above 0.5 as recommended by (Hair et al., 2010; Henseler et al., 2016b). Additionally, discriminant validity was explored using the Fornell-Lacker (1981) 
criterion and the HTMT test as suggested by (Henseler et al. 2015). Both tests as shown in Table 3 and 4 respectively, confirming the existence of discriminant validity in the constructs.

\section{Structural Model Assessment}

The hypothesis and construct relationship were tested using the standardized path coefficients. The path's significance level was calculated through the bootstrap resampling procedure (Henseler et al., 2009). The study initially examined the direct effect model (without the moderator) before testing the interaction models (with the moderator). This was done to determine the moderator effects. Results of the two (2) direct effects and the moderator model are presented in table 5 below.

The study hypothesized two (2) direct effects; thus, the study hypothesized that market knowledge acquisition which comprised of Customer Knowledge and Competitor Knowledge has a statistically significant effect on product innovation performance (PIP). The result indicates all the two (2) hypotheses were supported. Specifically, Customer Knowledge and Competitor Knowledge were discovered to have a statistically significant effect on product innovation performance (PIP) $(B=0.604 ; t=17.670$ : $B=0.402 ; t=8.846)$. However, the indirect relationship (moderator) did not show a statistically significant effect on the Customer Knowledge and Competitor Knowledge relationship.

Despite the improvement of the coefficient of determination $\left(R^{2}\right)$ as a result of including the moderator in the model, the effect was statistically insignificant. Thus, adding the Customer Knowledge to the model improved the strength of the model from $36 \%$ to $44 \%$, however, the effect was not statistically significant. Again, including Competitor Knowledge in the model also improved the model from $16 \%$ to $31 \%$, however, the effect was not statistically significant. The study additionally examined the change in $R^{2}$ to evaluate the interaction effect using the Cohen's $\mathrm{f} 2$ as shown below:

Cohen's $\mathrm{f}^{2}==\frac{\text { Rsq (interaction model) }- \text { Rsq (main effect model) }}{1-\text { Rsq (interaction model) }}$

According to Cohen (1988), the $\mathrm{f}^{2}$ value of 0.002 indicates that the moderating effect is small, 0.15 is medium while 0.35 is considered significant. Based on the result of Cohen's $f$ 2 statistic, the effect size of the Firm Absorptive Capacity as a whole on Customer knowledge and Product Innovation Performance with the value of 0.182 has a moderate effect size. Also, the effect size of the Firm Absorptive Capacity as a whole on Competitor knowledge and Product Innovation Performance with the value of 0.260 has a moderate effect size.

Table 6: Hypotheses Testing

\begin{tabular}{|c|c|c|c|c|c|c|}
\hline \multirow[b]{2}{*}{ Hypotheses } & \multicolumn{2}{|c|}{ DIRECT EFFECT } & \multicolumn{4}{|c|}{ MODERATOR EFFECT } \\
\hline & $\begin{array}{l}\text { Path } \\
\text { Coefficient }\end{array}$ & $\begin{array}{l}\mathrm{T} \\
\text { Statistics }\end{array}$ & $\mathbf{R}^{2}$ & $\begin{array}{l}\text { Path } \\
\text { Coefficient }\end{array}$ & $\begin{array}{l}\mathrm{T} \\
\text { Statistics }\end{array}$ & $\mathbf{R}^{2}$ \\
\hline $\mathrm{H}_{0} 1:$ CUK -> PIP & 0.604 & 17.670 & .358 & - & - & - \\
\hline $\mathrm{H}_{0} 2: \mathrm{COK}->\mathrm{PIP}$ & 0.402 & 8.846 & .158 & - & - & - \\
\hline $\mathrm{H}_{0} 3 \mathrm{a}: \mathrm{FAC} \times \mathrm{CU}$ & & & & & & \\
\hline$->P I P$ & - & - & & -.022 & .676 & .439 \\
\hline $\mathrm{H}_{0} 3 \mathrm{~b}: \mathrm{FAC} \times \mathrm{COK}$ & & & & & & \\
\hline > PIP & - & - & & -.044 & 1.110 & .310 \\
\hline
\end{tabular}




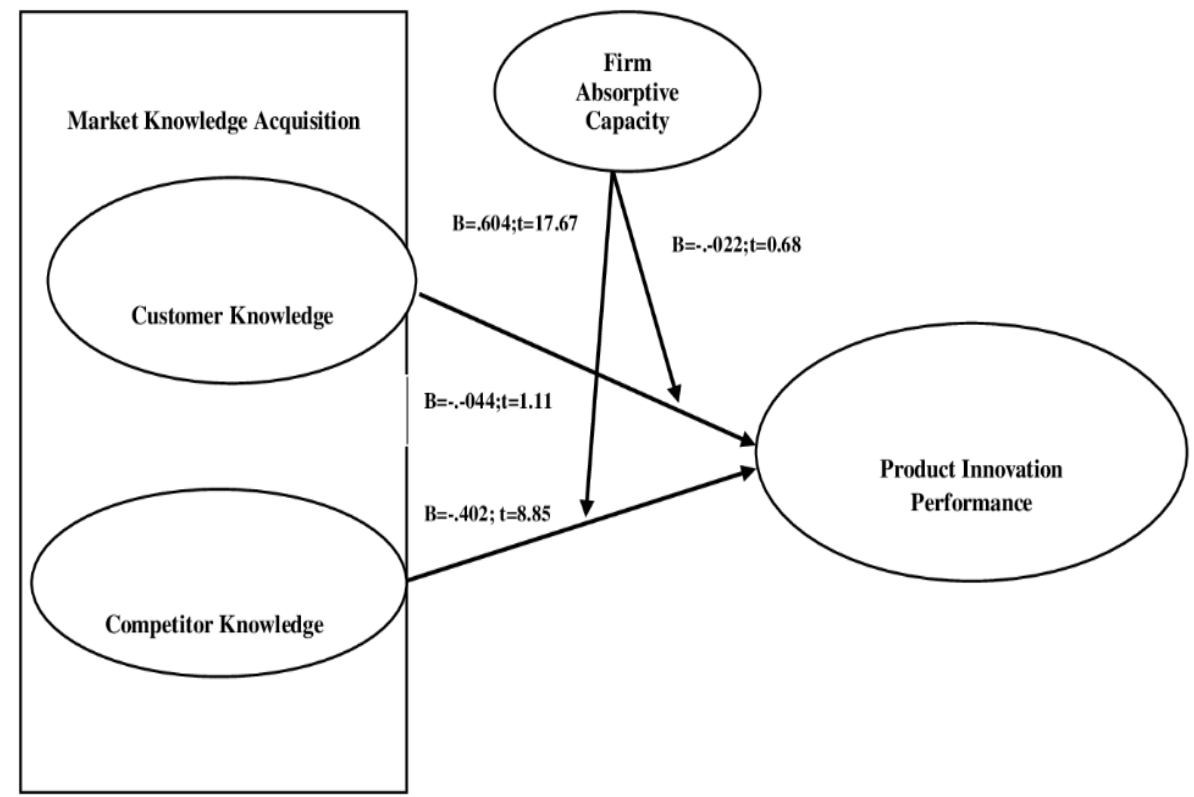

Figure 2: Measurement Model for SMEs Product Innovation Performance

\section{Findings and Conclusion}

The research outcome has unveiled the relevance of market knowledge in SME product innovation performance in Ghana. Firstly, Market Knowledge Acquisition which comprised of Customer Knowledge and Competitor Knowledge revealed a statistically significant effect on Product Innovation Performance. The study's main objective which is to investigate the firm's market knowledge acquisition (MKA) comprising customer and competitor knowledge, the moderating effect of firm absorptive capacity (FAC), and product innovation performance (PIP) was unravelled by correlation analysis of findings indicating a positive association between all the constructs (Customer Knowledge, Competitor Knowledge and Absorptive Capacity) and Product Innovation Performance among SMEs in Ghana ( $r=.414, P<.01 ; r=.224$, $\mathrm{P}<.01$ and $\mathrm{r}=.382, \mathrm{P}<.01$ ) respectively. The mean indications as per the descriptive analysis conducted, shows that Market Knowledge Acquisition (Customer Knowledge and Competitor Knowledge) and Firm Absorptive Capacity scored means of (CUK Mean $=4.18$; SD =0.647; COK Mean = 3.95; SD=0.786; FAC Mean = 3.65; SD=0.808; PIP Mean =4.21; SD=0.747). All the means were above 3.50 indicating that these factors play significant role in enhancing Product Innovation Performance among SMEs in Ghana. Thus, the higher level of customer knowledge, competitor Knowledge, and absorptive capacity is associated with higher product innovation performance among SMEs in Ghana.

The outcome brings to bear firms knowledge in market perspective can perceive timely and rapid changes in the market in improving their offerings. It is therefore evident from the current study that firms reporting increasing knowledge acquisition, such as combining issues in dealing with customers, competitors, market's participation report high levels of product innovation performance (Conceição et.al., 2017). Besides, SME market knowledge acquisition ensures an upper hand of the market dynamics in influencing innovation. The initial outcome of this study is not different from previous studies of (Conceição et al., 2017; Dwyer \& Gilmore, 2019; Evangelista \& Mac, 2016; Falasca et. al., 2017; Johansson, Raddats, \& Witell, 2019; Liu \& Atuahene-gima, 2018; Mostafiz, et al., 2019; Mostaghel, et al., 2019; Schaarschmidt \& Walsh, 2018; Secundo et al., 2020) which show that firms' market knowledge positively affects their innovation ability. This gives room for SME 
operators to focus more on acquiring knowledge through customer and competitor perspectives to influence their innovation drive (Deshpande, 2017).

Again, the study hypothesized that FAC moderates the relationship between Customer and Competitor Knowledge Acquisition and SME Product Innovation Performance. The result however indicated that Absorptive Capacity had an insignificant effect on the relationship in the context of SME operators. The study observed the improvement of the coefficient of determination $\left(R^{2}\right)$ as a result of including the moderator in the model, the effect was statistically insignificant. Thus, adding the Customer Knowledge to the model improved the strength of the model from $36 \%$ to $44 \%$, however, the effect was not statistically significant. Again, including Competitor Knowledge in the model also improved the model from $16 \%$ to $31 \%$, however, the effect was not statistically significant. Firm Absorptive Capacity as a whole on Customer knowledge and Product Innovation Performance with the value of 0.182 had a moderate effect size. Also, the effect size of the Firm Absorptive Capacity as a whole on Competitor knowledge and Product Innovation Performance with the value of 0.260 has a moderate effect size. This position does not come as a surprise as the majority of Ghanaian SMEs fail to make a human capital investment (Bandari, 2020) in enhancing growth in their firms.

Though the results of the first two direct effects which hypothesized that customer knowledge and competitor knowledge has a statistically significant effect on product innovation performance (PIP) were supported. That notwithstanding, the Absorptive Capacity of SMEs which was presented as a moderating variable in the study did not show a statistically significant effect on the customer knowledge and competitor knowledge relationship. Thus it is less impactful of SMEs Product Innovation Performance (Mubarik, Devadason, \& Govindaraju, 2020; Song, Gnyawali, Srivastava, \& Asgari, 2018; Tian, Dogbe, Pomegbe, Sarsah, \& Otoo, 2020).

SME operators would have to refocus and put in measure to absorb adequately the knowledge acquired (García-Sánchez, García-Morales, \& Martín-Rojas, 2018) to have a lasting bearing on the firm performance. It is therefore important to emphasize that though some businesses may have the potential to absorb new knowledge, they are unable to use the knowledge to stimulate the envisaged growth (Limaj \& Bernroider, 2019). The study, therefore, cautions against a direct generalization of absorption capacity of firms, especially the effects of absorption capacity through knowledge experience of SME operators on product innovation performance.

The current research makes several possibly beneficial insights, first, the effect of customer knowledge acquisition on SME product innovation performance has been measured, analyzed, and evaluated with competitor knowledge acquisition. This demonstrates to have never been done before, particularly the in Ghanaian manufacturing SMEs. Second, the absorptive capacity measurements used and evaluated in this study reveal the type and degree to which smaller manufacturing firms use diverse interpretation and declaration methods. Third, this is among the few studies that present statistically validated convincing proof interaction among customer and competitor information acquisition on the one side, as well as absorptive ability on the other, and how well the aforementioned contributes to the improvement of Ghanaian manufacturing SMEs. This work has effectively established a foundation for future studies on SME absorptive potential in achieving maximum market knowledge acquisition benefits. Finally, this study has demonstrated the other side of SME knowledge acquisition and knowledge absorptive ability under knowledge management topic, which still needs to be explored further in the case of developing nations. 


\section{Limitations and Future Research}

It would be worthwhile to look at how market knowledge acquisition can be done in non-manufacturing fields, and also how it can connect with product innovation capabilities.

Also, while this current sample size is comparable to the minimum required for this form of research, future research should attempt to reach a larger sample size to improve external validity. Again, the cross-sectional nature of the study presents the study only in the context within which it is presented. Other industries can be researched to expand literature in knowledge management. In addition, other dimensions of FAC on product innovation performance can be investigated.

Finally, government participation by can be researched to examine its influence on the relationship.

\section{References}

Ab Hamid, M. R., Sami, W., \& Sidek, M. M. (2017). Discriminant validity assessment: Use of Fornell \& Larcker criterion versus HTMT criterion. In Journal of Physics: Conference Series (Vol. 890, No. 1, p. 012163). IOP Publishing.

Ahiakpor, F., Asmah, E. E., \& Andoh, F. K. (2014). Firm Capacity Utilization in Ghana: Does Foreign Ownership Matter? Developing Country Studies, 4(4), 11-19.

Aljanabi, A. Q. R. A. (2018). The mediating role of absorptive capacity on the relationship between entrepreneurial orientation and technological innovation capabilities. International Journal of Entrepreneurial Behaviour and Research, 24(4), 818-841.

AlQershi, N. A., Mokhtar, S. S. M., \& Abas, Z. Bin. (2020). CRM dimensions and performance of SMEs in Yemen: the moderating role of human capital. Journal of Intellectual Capital.

Aminu, S. A., \& Polytechnic, L. S. (2018). Market orientation and small and medium enterprises' ( SMEs ) performance in Nigeria : A review, (August).

Bandari, C. (2020). Human Resource Management Practices for Sustainability of Ghanaian Small and Medium Enterprises Walden University.

Bojica, A. M., \& Fuentes-fuentes, M. M. (2019). Knowledge Acquisition and Corporate Entrepreneurship : Insights from Spanish SMEs in the ICT Sector, (July 2012).

Carson, G., O'Connor, C., \& Simmons, G. (2020). The crucial role of market intelligence in the development of small business marketing capabilities. Journal of Small Business and Enterprise Development, 27(5), 797-816.

Cohen, W. M., \& Levinthal, D. A. (1990). Absorptive Capacity: A New Perspective on Learning and Innovation. Administrative Science Quarterly, 35(1), 128.

Conceição, J., Camargo, S. M., Maria, A., Toaldo, M., \& Didonet, S. R. (2017). The role of marketing capabilities, absorptive capacity, and innovation performance, (Mic).

Dabrowski, D. (2019). Market knowledge and new product performance: The mediating effects of new product creativity. Journal of Business Economics and Management, 20(6), 1168-1188.

Davcik, N. S., Cardinali, S., Sharma, P., \& Cedrola, E. (2020). Exploring the role of international R\&D activities in the impact of technological and marketing capabilities on SMEs' performance. Journal of Business Research, (April 2019).

Deshpande, M. (2017). Policy Perspectives for SMEs Knowledge Management, 23-46.

Dwyer, M. O., \& Gilmore, A. (2019). Competitor orientation in successful SMEs: an exploration of the impact on innovation. Journal of Strategic Marketing, 4488, 1-17.

Evangelista, F., \& Mac, L. (2016). The influence of experience and deliberate learning on SME export performance. International Journal of Entrepreneurial Behavior \& Research, 860- 
879.

Expósito, A., \& Sanchis, J. A. (2019). The relationship between types of innovation and SMEs' performance : a multi - dimensional empirical assessment. Eurasian Business Review, 9(2), 115-135.

Falasca, Mauro; Zhang, J., \& Conchar, Margy; Li, L. (2017). The impact of customer knowledge and marketing dynamic capability on innovation performance : an empirical analysis. Journal of Business \& Industrial Marketing, 7(March), 901-912.

Ferraris, A., Devalle, A., Ciampi, F., \& Couturier, J. (2019). Are global R\&D partnerships enough to increase a company's innovation performance? The role of search and integrative capacities. Technological Forecasting and Social Change, 149(November), 119750.

Ferreira, A., \& Franco, M. (2019). The influence of strategic alliances on human capital development: A study applied to technology-based SMEs. EuroMed Journal of Business, 15(1), 65-85.

Flor, M. L., Cooper, S. Y., \& Oltra, M. J. (2018). External knowledge search, absorptive capacity and radical innovation in high-technology firms. European Management Journal, 36(2), 183-194.

Fong, S.-F., Lo, M.-C., \& Ramayah, T. (2014). New Product Development and Performance in the Banking Industry. Asia-Pacific Journal of Management Research and Innovation, 10(4), 305-321.

Fu, X., Mohnen, P., \& Zanello, G. (2018). Innovation and productivity in formal and informal firms in Ghana. Technological Forecasting and Social Change, 131, 315-325.

García-Sánchez, E., García-Morales, V. J., \& Martín-Rojas, R. (2018). Influence of technological assets on organizational performance through absorptive capacity, organizational innovation and internal labour flexibility. Sustainability (Switzerland), 10(3).

Hameed, W. U., Basheer, M. F., Iqbal, J., Anwar, A., \& Ahmad, H. K. (2018). Determinants of Firm's open innovation performance and the role of $R \& D$ department: an empirical evidence from Malaysian SME's. Journal of Global Entrepreneurship Research, 8(1).

He, Q., Guaita-Martínez, J. M., \& Botella-Carrubi, D. (2020). How brand equity affects firm productivity: The role of R\&D and human capital. Economic Research-Ekonomska Istrazivanja , 33(1), 2976-2992.

Herman, H., Hady, H., \& Arafah, W. (2018). The Influence of Market Orientation and Product Innovation on the Competitive Advantage and Its Implication toward Small and Medium Enterprises ( UKM ) Performance, 04(08), 8-21.

Hilmersson, M., \& Johanson, M. (2020). i s b j Knowledge acquisition strategy, speed of capability development and speed of SME internationalisation.

Hoe, S. L. (2008). Benefiting from customer and competitor knowledge: A market-based approach to organizational learning. Learning Organization, 15(3), 240-250.

Johansson, A. E., Raddats, C., \& Witell, L. (2019). The role of customer knowledge development for incremental and radical service innovation in servitized manufacturers. Journal of Business Research, 98(September 2017), 328-338.

Kalay, F., \& Lynn, G. S. (2015). THE IMPACT OF STRATEGIC INNOVATION MANAGEMENT PRACTICES ON FIRM INNOVATION PERFORMANCE 2 . THEORETICAL BACKGROUND AND HYPOTHESES, 412-429.

Kumar, D., \& Rahman, Z. (2015). Sustainability adoption through buyer supplier relationship across supply chain: A literature review and conceptual framework. International Strategic Management Review (Vol. 3). Holy Spirit University of Kaslik.

Leng, Z., Liu, Z., Tan, M., \& Pang, J. (2015). Speed leaders and quality champions: Analyzing 
the effect of market orientation and technology orientation alignment on new product innovation. Management Decision, 53(6), 1247-1267.

Lewandowska, M. S. (2015). Capturing Absorptive Capacity: Concepts, Determinants, Measurement Modes and Role in Open Innovation. International Journal of Management and Economics, 45(1), 32-56.

Li, Y., Xie, E., \& Cheng, L. (2017). The effect of market orientation on new product development: a literature review. Chinese Management Studies, 11(4), 582-598.

Liao, Y., \& Barnes, J. (2015). Knowledge acquisition and product innovation flexibility in SMEs. Business Process Management Journal, 21(6), 1257-1278.

Limaj, E., \& Bernroider, E. W. N. (2019). The roles of absorptive capacity and cultural balance for exploratory and exploitative innovation in SMEs. Journal of Business Research, 94(November 2017), 137-153.

Lin, B., Chen, C., Lin, B., \& Chen, C. (2007). Fostering product innovation in industry networks : the mediating role of knowledge integration Fostering product innovation in industry networks : the mediating role of knowledge integration. The International Journal of Human Resource Management, 17:1, 155-173,

Liu, W., \& Atuahene-gima, K. (2018). Enhancing product innovation performance in a dysfunctional competitive environment : The roles of competitive strategies and marketbased assets it. Industrial Marketing Management, 73(December 2016), 7-20.

Liu, W., \& Atuahene-Gima, K. (2018). Enhancing product innovation performance in a dysfunctional competitive environment: The roles of competitive strategies and marketbased assets. Industrial Marketing Management, 73(December 2017), 7-20.

Maduekwe, C. C., Africa, S., Kamala, P., \& Africa, S. (2016). Performance measurement by small and medium enterprises in Cape Metropolis, South Africa, 14(2).

Mensah, I. (2019). Marketing innovation and sustainable competitive advantage of manufacturing SMEs in Ghana Article information :, (October 2018).

Mostafiz, Mdlmtiaz; Sambasivan, Murali; Goh, S. K. (2019). The antecedents and the outcomes of foreign market knowledge accumulation - the dynamic managerial capability perspective. Journal of Business \& Industrial Marketing, 4(March), 902-920.

Mostaghel, R., Oghazi, P., Patel, P. C., Parida, V., \& Hultman, M. (2019). Marketing and supply chain coordination and intelligence quality: A product innovation performance perspective. Journal of Business Research, 101(March), 597-606.

Mubarik, M. S., Devadason, E. S., \& Govindaraju, C. (2020). Human capital and export performance of small and medium enterprises in Pakistan. International Journal of Social Economics, 47(5), 643-662.

Muscio, A. (2007). THE IMPACT OF ABSORPTIVE CAPACITY ON SMEs ' COLLABORATION. Economics of Innovation and New Technology, 16:8, 653-668, 8599.

Najafi-Tavani, S., Najafi-Tavani, Z., Naudé, P., Oghazi, P., \& Zeynaloo, E. (2018). How collaborative innovation networks affect new product performance: Product innovation capability, process innovation capability, and absorptive capacity. Industrial Marketing Management, 73(May 2016), 193-205.

Nastasiea, M., \& Mironeasa, C. (2015). Key Performance Indicators in Small and Medium Sized Enterprises, i, 46-53. Retrieved from http://www.fim.usv.ro/conf_1/tehnomusjournal/pagini/journal2016/files/8.pdf

Olaru, M., Pirnea, I. C., Hohan, A., \& Maftei, M. (2014). Performance Indicators Used by SMEs in Romania, Related to Integrated Management Systems. Procedia - Social and Behavioral Sciences, 109, 949-953. 
Salehi, Y. (2017). Investigate the Relationship between Organizational Learning Capabilities and Organizational Innovation in The Food Industry (Subsidiary Industrial Estates of Kermanshah Province ), 8(1), 84-97.

Santoro, G., Ferraris, A., \& Winteler, D. J. (2019). Open innovation practices and related internal dynamics: case studies of Italian ICT SMEs. EuroMed Journal of Business, 14(1), 47-61.

Schaarschmidt, M., \& Walsh, G. (2018). Customer Interaction and Innovation in Hybrid Offerings: Investigating Moderation and Mediation Effects for Goods and Services Innovation, 21(1), 119-134.

Secundo, G., Del, P., Simeone, L., \& Schiuma, G. (2020). Creativity and stakeholders ' engagement in open innovation: Design for knowledge translation in technologyintensive enterprises. Journal of Business Research, 119(April 2018), 272-282.

Shane, S. (2000). Prior Knowledge and the Discovery of Entrepreneurial Opportunities, 11(4), 448-469.

Sinisammal, J., Belt, P., Harkonen, J., Mottonen, M., \& Vayrynen, S. (2012). Successful Performance Measurement in SMEs through Personnel Participation. American Journal of Industrial and Business Management, 02(02), 30-38.

Song, Y., Gnyawali, D. R., Srivastava, M. K., \& Asgari, E. (2018). In Search of Precision in Absorptive Capacity Research: A Synthesis of the Literature and Consolidation of Findings. Journal of Management, 44(6), 2343-2374.

Sousa, J. P., Krot, K., \& Rodrigues, R. G. (2018). Internal marketing and organisational performance of SMEs in the EDV industrial sector. Engineering Management in Production and Services, 10(1), 55-64.

Storey, C., \& Larbig, C. (2018). Absorbing Customer Knowledge : How Customer Involvement Enables Service Design Success, 21(1), 101-118.

Taghizadeh, S. K., Rahman, S. A., \& Hossain, M. M. (2018). Knowledge from customer, for customer or about customer: which triggers innovation capability the most? Journal of Knowledge Management, 22(1), 162-182.

Thomä, J., \& Zimmermann, V. (2020). Interactive learning - The key to innovation in nonR\&D-intensive SMEs? A cluster analysis approach. Journal of Small Business Management, 58(4), 747-776.

Thongsri, N., \& Chang, A. K. H. (2019). Interactions among factors influencing product innovation and innovation behaviour: Market orientation, managerial ties, and government support. Sustainability (Switzerland), 11(10).

Tian, H., Dogbe, C. S. K., Pomegbe, W. W. K., Sarsah, S. A., \& Otoo, C. O. A. (2020). Organizational learning ambidexterity and openness, as determinants of SMEs' innovation performance. European Journal of Innovation Management.

Tuan, N., Nhan, N., Giang, P., \& Ngoc, N. (2016). The effects of innovation on firm performance of supporting industries in Hanoi - Vietnam. Journal of Industrial Engineering and Management, 9(2), 413-431.

Uğurlu, Ö. Y., Kurt, M., \& Kurt, M. (2016). The Impact of Organizational Learning Capability on Product Innovation Performance : Evidence from the Turkish Manufacturing Sector The Impact of Organizational Learning Capability on Product Innovation Performance: Evidence from the Turkish Manufacturin, 6(1).

Varadarajan, R. (2020). Customer information resources advantage, marketing strategy and business performance: A market resources based view. Industrial Marketing Management, 89(March), 89-97. 
Verhees, F. J. H. M., \& Meulenberg, M. T. G. (2004). Market Orientation, Innovativeness, Product Innovation, and Performance in Small Firms *, 42(2), 134-154.

Vlačić, E., Dabić, M., Daim, T., \& Vlajčić, D. (2019). Exploring the impact of the level of absorptive capacity in technology development firms. Technological Forecasting and Social Change, 138(August 2018), 166-177.

Wadho, W., \& Chaudhry, A. (2018). Innovation and firm performance in developing countries: The case of Pakistani textile and apparel manufacturers. Research Policy, 47(7).

Wang, Y., \& Wang, Y. (2016). Learning and innovation in small and medium enterprises, (March 2010).

Yachin, J. M. (2018). The 'customer journey': Learning from customers in tourism experience encounters. Tourism Management Perspectives, 28(February), 201-210. 